\title{
The Effects of Stocking Density on the Growth and Survival of Nile Tilapia (Oreochromis niloticus) Fry at Son Fish Farm, Uganda
}

\author{
Ntanzi Ronald*, Bwanika Gladys and Eriku Gasper
}

Fisheries and Aquaculture, Makerere university, Uganda

\begin{abstract}
Besides affecting land usability that subsequently impacting on profitability of an aquaculture venture, stocking density is believed to affect growth rate and survival of fish species stocked. In this study, Nile tilapia fry were randomly stocked at densities 1000,1330,2000, 2670, 4000 and $5330 \mathrm{fry} / \mathrm{m}^{3}$ for an experimental period of 23 days. All fish were fed a commercial feed (45\% protein) at levels of 20,18 and $15 \%$ body weight in week one, two and three. The impact of stocking density on standard length, body weight, survival, growth homogeneity, specific growth rate and feed conversion ratios was determined on samples taken weekly for the experimental. A negative correlation between stocking density and growth rate was recorded. Survival was lowest with high stocking densities, $87 \%$ at $4000 \mathrm{fry} / \mathrm{m}^{3}$ and 82.9 at $5330 \mathrm{fry} / \mathrm{m}^{3}$. Results demonstrate that increasing the stocking density of Nile tilapia fry beyond $2670 \mathrm{fry} / \mathrm{m}^{3}$ significantly affects survival and growth of fry (ANOVA).
\end{abstract}

Keywords: Fish farm; Nile tilapia

\section{Introduction}

\section{Background}

Tilapias are the world's second most important fish species for aquaculture after the carp and this is due to their high growth rates, being prolific breeders, completing their life cycle in captivity, tolerance to environmental stress and high market demand [1]. Nile tilapia culture in Uganda traces way back in the late 1940's just after it had proved to do better than the carp in Uganda according to experiments that were carried out at the by then Kajjansi Experimental Station [2] The culture of Tilapia expanded exponentially until a more recent overtake by the catfish making Tilapia now, Uganda's second most cultured fish species. Nile tilapia is widely accepted on the Ugandan local market, regional markets and is also exported to the European market. Furthermore, the declining capture fisheries worldwide, (Gabriel et al., 2007 drives an increased need for aquaculture expansion in order to bridge the gap between production and demand. For Uganda, this new wave of aquaculture would be fully endowed by small scale farmers if they had adequate knowledge on the appropriate Nile tilapia fry stocking densities as it is believed to be a critical husbandry practice that can boost the production capacity and efficiency of a culture system [3] in addition to determining the economic viability of production system in intensive aquaculture [4]. Stocking densities of Nile tilapia fry normally range from 3000 to $4000 \mathrm{fry} / \mathrm{m}^{3}$. However a stocking density as high as $20,000 \mathrm{fry} / \mathrm{m}^{3}$ is also practical given good water quality [5]. SON Fish Farm is currently using a stocking density of $4000 \mathrm{fry} / \mathrm{m}^{3}$ in $2 \times 1 \times 1$ meter hapas and most fish farms in Uganda don't deviate much from this density. However, the basis of this stocking density is not justified and the definite best stocking density is not known. It is on the basis of this knowledge gap that the current study was proposed.

\section{Problem statement}

Fish farmers in Uganda in the grow-out sector often face low yield that culminates in low profit margins given input costs. This setback, to some extent stems from lack of sufficient knowledge on the best practice of fry stocking densities in hapas or nursery ponds that would maximize production. For this reason, a study was proposed to address the concern in a local setting that could be representative of various potential fish farm sites in central Uganda.

\section{Justification}

The research was envisaged to give knowledge on appropriate stocking density of tilapia fry that would maximize production and profitability of grow-out aquaculture enterprises.

\section{Objectives of the study}

Major objective: To establish the most appropriate stocking densities for Nile tilapia fry in hapas set in earthen ponds.

Specific objectives: To investigate the effects of stocking density on feed conversion ratios (FCR) of Nile tilapia stocked in hapas in earthen ponds.

- To determine the effect of stocking density on growth homogeneity of Nile tilapia fry in hapas in earthen ponds.

- To compare the growth (daily weight gain (DWG) and specific growth rate (SGR) rate) at different stocking densities.

- To determine the survival rate of Nile tilapia fry at various stocking densities.

\section{Hypotheses}

$\mathrm{H}_{\mathrm{o}}$ : Stocking density does not affect feed conversion ratios in Tilapias

$\mathrm{H}_{\mathrm{o}}$ : Stocking density does not affect growth homogeneity of Nile tilapia fry.

$\mathrm{H}_{\mathrm{o}}$ : Stocking density does not affect growth of Nile tilapia fry.

*Corresponding author: Ntanzi Ronald, Fisheries and Aquaculture, Makerere university, Uganda, Tel: 256 256414534343; E-mail: ntanzironald@yahoo.com

Received December 23, 2013; Accepted February 16, 2014; Published February 26, 2014

Citation: Ronald N, Gladys B, Gasper E (2014) The Effects of Stocking Density on the Growth and Survival of Nile Tilapia (Oreochromis niloticus) Fry at Son Fish Farm, Uganda. J Aquac Res Development 5: 222 doi:10.4172/2155-9546.1000222

Copyright: $\odot 2014$ Ronald N, et al. This is an open-access article distributed under the terms of the Creative Commons Attribution License, which permits unrestricted use, distribution, and reproduction in any medium, provided the original author and source are credited. 
Citation: Ronald N, Gladys B, Gasper E (2014) The Effects of Stocking Density on the Growth and Survival of Nile Tilapia (Oreochromis niloticus) Fry at Son Fish Farm, Uganda. J Aquac Res Development 5: 222 doi:10.4172/2155-9546.1000222

Page 2 of 7 density.

$\mathrm{H}_{\mathrm{o}}$ : Survival rate of Nile tilapia fry is independent of stocking

\section{Methods and Materials}

\section{Study site}

The research was carried out at Source of the Nile (SON) fish farm, a mono-sex tilapia culture fish farm located in Bugungu, Njeru sub county in Buikwe district. One of the primary nursing ponds at this farm (G ponds) were used for the experiment (Figure 1).

\section{Research design}

The case study involved stocking Nile tilapia fry at different stocking densities and maintaining uniform management practices for a period of four weeks. Data was collected weekly to assess impact of stocking density on survival and growth of fry.

\section{Experimental design}

Two replicates were used for each treatment and these were fed on $20 \%, 18 \%$ and $15 \%$ body weight in week 1,2 and three respectively. This was done using a $45 \%$ crude protein feed.

\section{Specific methods}

Harvested fry of mean length $12.4 \pm 0.16 \mathrm{~mm}$ and mean weight of $0.03 \pm 0.0016 \mathrm{~g}$ originating from the same brood were randomly selected and stocked in hapas in various stocking densities that is; $1000 \mathrm{fry} / \mathrm{m}^{3}, 1330 \mathrm{fry} / \mathrm{m}^{3}, 2000 \mathrm{fry} / \mathrm{m}^{3}, 2670 \mathrm{fry} / \mathrm{m}^{3}, 4000 \mathrm{fry} / \mathrm{m}^{3}$ and $5330 \mathrm{fry} / \mathrm{m}^{3}$, respectively . Fish were fed manually with $20 \%, 18 \%$, and $15 \%$ of body weight daily for the first week, second week and for the rest of the experiment duration, respectively. Aquatro feeds ( $45 \%$ crude protein) obtained from Livestock Feeds Limited (LFL) in Mauritius were used for three weeks with a feeding frequency of eight rounds per day. Every after one week, measurements were carried out on fish fry between 09:00 -11:30 am depending on the weather of the day and finally at the time of grading. Standard length and body weight were taken to the nearest millimeter and nearest $0.01 \mathrm{~g}$, respectively using calibrated graph paper and a mini digital pocket gram scale. The fish were removed from the hapas between the $24^{\text {th }}$ and $25^{\text {th }}$ day and graded. To determine survival at grading time, number of fish in the hapa was established and computed against the number at stocking.

Growth performance analysis: Fish Growth Performance was evaluated basing on Specific Growth Rate (SGR), Food conversion Ratio (FCR), Survival Rate (SR) and Daily Weight Gain (DWG) using the formulae below:

$$
\text { SGR }(\% \text { per day })=\frac{(\operatorname{Logn} W f-\operatorname{Longn} W s)}{T} \times 100
$$

Where: $\quad \mathrm{Wf}=$ Final weight of fish; Ws $=$ Weight of fish at Start; $\mathrm{T}=$ Duration of nursing

$$
\begin{aligned}
& \text { FCR }=\frac{\text { amount of dry food int age }(g)}{\text { Fresh weight gain in fish }} \\
& \text { SR -Survival rate }(\%)=\frac{\text { Final harvested amount }}{\text { Stocked amount }} \times 100 \\
& \text { DWG -Daily Weight Gain }=\frac{\text { Fresh weight gain in fish }(\mathrm{g})}{\text { Duration of nursing }}
\end{aligned}
$$

\section{Statistical analysis}

Data collected from the experiment was analyzed using one-way ANOVA and when ANOVA indicated that there was a statistical difference between the stockings densities means, Tukeys Tests were used to compare these means. The software of statistics calculations and model was SPSS statistics version 20 and all statistical tests considered significant at $(\mathrm{P}<0.05)$.

\section{Results}

\section{Length and weight}

The mean length at the beginning of the experiment and at week one sampling were not significant for all the stocking densities ( $\mathrm{P}$ $=1.0$ and 0.192 , respectively). At sampling two (week two) there was a significance difference in the mean length of all the three samples $(\mathrm{P}<0.0001)$. Tukeys test indicated a significance between the highest density of 5330 fry $/ \mathrm{m}^{3}$ and rest of the densities $(\mathrm{P}<0.0001)$ but no difference between densities 2000, 2670 and 4000 fry $/ \mathrm{m}^{3}$ and 1330 fry/ $\mathrm{m}^{3}(\mathrm{P}=0.331,0.955$ and 0.978 , respectively). By week three, fry stocked at $1000 \mathrm{~m}^{3}$ exhibited the highest final mean length $(27.471+/-0.331)$ while fry stocked at $5330 \mathrm{~m}^{3}$ recorded the lowest $(22.804+/-0.222)$. By the end of the experiment, the mean length of the six stocking densities was significantly different $(\mathrm{P}<0.0001)$.

The relationships between stocking density and mean length at week one, two and three samplings are shown in Figure 2.

All the stocking densities showed a gradual increase in weight with density of $1000 \mathrm{fry} / \mathrm{m}^{3}$ having the greatest gain from $0.03 \mathrm{~g}$ average body weight at stocking to $0.43 \pm 0.057$ whilst $5330 \mathrm{fry} / \mathrm{m}^{3}$ registered the lowest from 0.03 average body weight at stocking to $0.24 \pm 0.042 \mathrm{~g}$ by grading time (Figure 3 ).

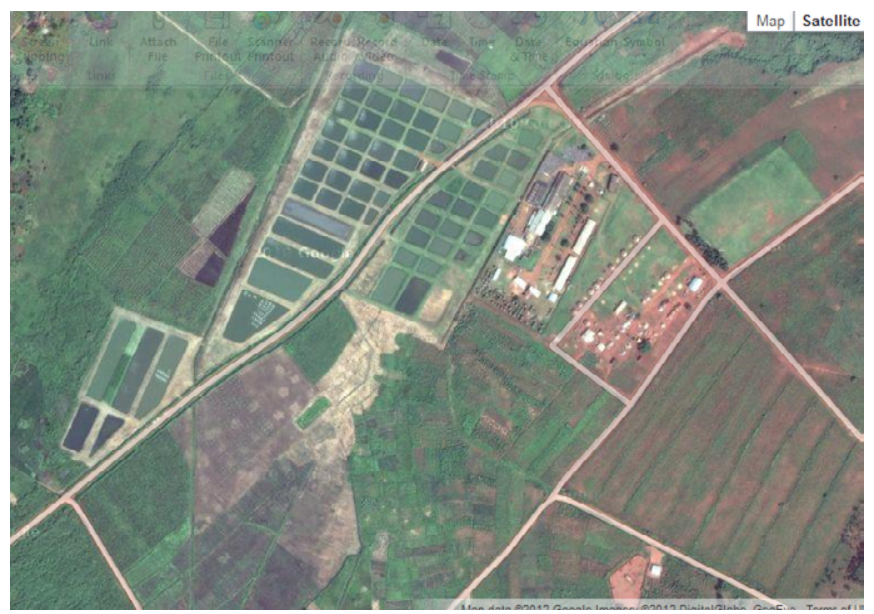

Figure 1: An Aerial view of Son fish farm showing the $G$ ponds (primary nursing ponds).

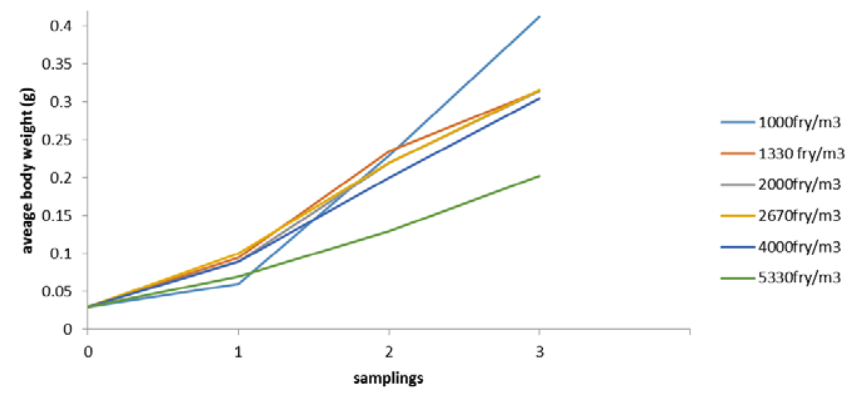

Figure 2: The relationship between mean standard length and stocking density of fry at for the three samplings. 


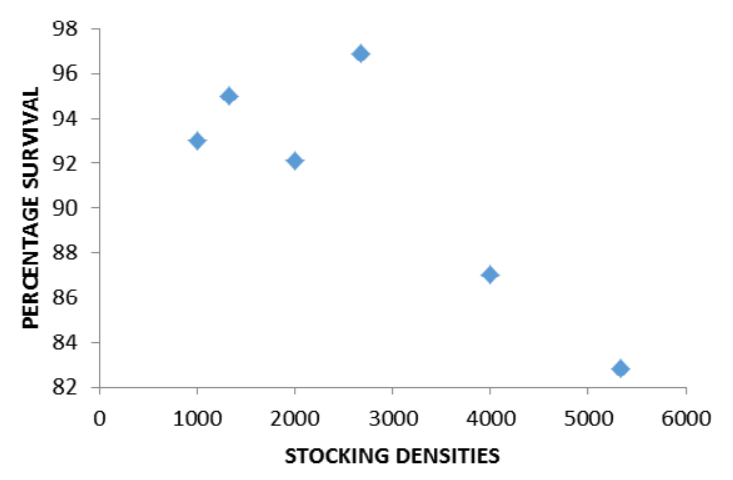

Figure 3: Relationship between average body weight and time samplings

\section{Survival rate}

From the experiment, the results were divided into two groups depending on the percentage survival. The first group had stocking densities $2670,1330,1000$, and $2000 \mathrm{fry} / \mathrm{m}^{3}$ in order of decreasing survival but all having high survivals of above $90 \%$. The second group had densities 4000 and $5330 \mathrm{fry} / \mathrm{m}^{3}$ and these had less than than $90 \%$ as far as survival is concerned (Table 1).

There existed a high negative correlation between survival and stocking density $(\mathrm{P}=-0.835)$ (Figure 4$)$.

\begin{tabular}{|c|c|c|c|c|c|c|}
\hline & & $\begin{array}{l}\text { 1ST SAMLING } \\
\text { ON } 15 / 6 / 12\end{array}$ & & & & \\
\hline 1000 & 1330 & 2000 & 2670 & 4000 & 5330 & STOCKING 6/6/12 \\
\hline 17 & 18 & 17 & 20 & 16 & 16 & 11 \\
\hline 19 & 16 & 17 & 19 & 13 & 14 & 12 \\
\hline 14 & 15 & 16 & 18 & 16 & 12 & 11 \\
\hline 18 & 13 & 19 & 14 & 20 & 12 & 12 \\
\hline 16 & 17 & 18 & 20 & 15 & 15 & 11 \\
\hline 15 & 17 & 16 & 16 & 14 & 14 & 12 \\
\hline 20 & 12 & 15 & 15 & 13 & 15 & 13 \\
\hline 15 & 18 & 20 & 17 & 15 & 16 & 13 \\
\hline 18 & 18 & 20 & 14 & 16 & 17 & 13 \\
\hline 14 & 15 & 20 & 19 & 20 & 15 & 14 \\
\hline 16 & 16 & 15 & 20 & 16 & 18 & 13 \\
\hline 13 & 17 & 16 & 15 & 15 & 20 & 11 \\
\hline 16 & 16 & 19 & 14 & 20 & 22 & 13 \\
\hline 16 & 19 & 19 & 16 & 18 & 18 & 13 \\
\hline 15 & 19 & 14 & 18 & 13 & 15 & 12 \\
\hline 19 & 18 & 19 & 16 & 19 & 20 & 10 \\
\hline 18 & 16 & 20 & 17 & 14 & 18 & 11 \\
\hline 14 & 15 & 13 & 14 & 14 & 15 & 11 \\
\hline 17 & 19 & 15 & 15 & 14 & 16 & 14 \\
\hline 14 & 14 & 14 & 14 & 17 & 14 & 15 \\
\hline 14 & 12 & 14 & 19 & 20 & 19 & 13 \\
\hline 20 & 20 & 18 & 18 & 16 & 15 & 11 \\
\hline 15 & 17 & 20 & 16 & 19 & 16 & 12 \\
\hline 15 & 16 & 13 & 16 & 13 & 16 & 11 \\
\hline 14 & 15 & 15 & 16 & 15 & 13 & 13 \\
\hline 14 & 19 & 14 & 17 & 15 & 13 & 12 \\
\hline 13 & 17 & 14 & 17 & 14 & 14 & 12 \\
\hline 14 & 18 & 18 & 18 & 16 & 18 & 13 \\
\hline 18 & 16 & 20 & 15 & 14 & 12 & 12 \\
\hline 15 & 23 & 15 & 19 & 18 & 18 & 13 \\
\hline 14 & 15 & 14 & 18 & 19 & 15 & 12 \\
\hline
\end{tabular}

\begin{tabular}{|c|c|c|c|c|c|c|}
\hline 14 & 20 & 15 & 14 & 14 & 17 & 15 \\
\hline 10 & 12 & 13 & 15 & 17 & 18 & 11 \\
\hline 19 & 16 & 15 & 16 & 17 & 17 & 13 \\
\hline 17 & 17 & 14 & 17 & 16 & 19 & 14 \\
\hline 14 & 16 & 15 & 14 & 16 & 17 & 11 \\
\hline 16 & 17 & 18 & 16 & 13 & 16 & 13 \\
\hline 16 & 15 & 16 & 14 & 16 & 16 & 13 \\
\hline 19 & 16 & 19 & 20 & 20 & 12 & 14 \\
\hline 20 & 18 & 15 & 16 & 17 & 12 & 13 \\
\hline 17 & 16 & 15 & 20 & 15 & 13 & 14 \\
\hline 15 & 17 & 20 & 21 & 15 & 14 & 13 \\
\hline 17 & 14 & 19 & 15 & 16 & 16 & 11 \\
\hline 19 & 15 & 19 & 14 & 15 & 17 & 11 \\
\hline 18 & 19 & 18 & 16 & 14 & 16 & 12 \\
\hline 17 & 18 & 14 & 15 & 12 & 14 & 12 \\
\hline 21 & 16 & 20 & 19 & 13 & 18 & 12 \\
\hline 20 & 12 & 17 & 16 & 15 & 14 & 13 \\
\hline 17 & 17 & 14 & 17 & 16 & 19 & 14 \\
\hline \multirow[t]{2}{*}{19} & 20 & 14 & 17 & 15 & 13 & 12 \\
\hline & & $\begin{array}{l}\text { 2nd SAMPLING } \\
\text { ON 23/6/12 }\end{array}$ & & & & \\
\hline 1000 & 1330 & 2000 & 2670 & 4000 & 5330 & \\
\hline 20 & 17 & 20 & 16 & 20 & 19 & \\
\hline 24 & 22 & 21 & 20 & 23 & 19 & \\
\hline 25 & 20 & 20 & 19 & 20 & 18 & \\
\hline 26 & 22 & 23 & 19 & 20 & 17 & \\
\hline 23 & 22 & 24 & 20 & 22 & 17 & \\
\hline 22 & 22 & 22 & 22 & 22 & 21 & \\
\hline 20 & 20 & 24 & 18 & 21 & 21 & \\
\hline 27 & 23 & 21 & 20 & 20 & 17 & \\
\hline 24 & 23 & 18 & 19 & 19 & 18 & \\
\hline 30 & 17 & 20 & 24 & 21 & 21 & \\
\hline 23 & 20 & 24 & 25 & 20 & 19 & \\
\hline 23 & 19 & 20 & 25 & 23 & 18 & \\
\hline 24 & 24 & 23 & 19 & 23 & 17 & \\
\hline 28 & 23 & 24 & 25 & 20 & 14 & \\
\hline 22 & 22 & 23 & 19 & 24 & 18 & \\
\hline 23 & 17 & 23 & 25 & 22 & 18 & \\
\hline 24 & 20 & 20 & 25 & 20 & 16 & \\
\hline 20 & 19 & 24 & 20 & 21 & 20 & \\
\hline 22 & 24 & 22 & 20 & 20 & 18 & \\
\hline 19 & 23 & 22 & 24 & 26 & 16 & \\
\hline 21 & 22 & 25 & 22 & 21 & 18 & \\
\hline 22 & 17 & 20 & 23 & 20 & 20 & \\
\hline 18 & 20 & 24 & 20 & 23 & 21 & \\
\hline 26 & 20 & 24 & 22 & 24 & 22 & \\
\hline 20 & 25 & 23 & 22 & 22 & 15 & \\
\hline 22 & 23 & 20 & 18 & 22 & 16 & \\
\hline 22 & 18 & 22 & 21 & 21 & 16 & \\
\hline 26 & 22 & 22 & 22 & 20 & 16 & \\
\hline 22 & 19 & 25 & 20 & 20 & 20 & \\
\hline 22 & 20 & 20 & 25 & 23 & 15 & \\
\hline 20 & 17 & 19 & 19 & 20 & 21 & \\
\hline 22 & 17 & 20 & 20 & 20 & 17 & \\
\hline 26 & 25 & 24 & 17 & 22 & 17 & \\
\hline 18 & 20 & 20 & 19 & 22 & 19 & \\
\hline 21 & 20 & 23 & 18 & 22 & 18 & \\
\hline 20 & 22 & 21 & 24 & 22 & 17 & \\
\hline 22 & 25 & 20 & 20 & 24 & 16 & \\
\hline 26 & 25 & 23 & 22 & 20 & 21 & \\
\hline 18 & 23 & 21 & 19 & 16 & 16 & \\
\hline
\end{tabular}




\begin{tabular}{|c|c|c|c|c|c|c|}
\hline 21 & 18 & 24 & 20 & 20 & 20 & \\
\hline 27 & 23 & 26 & 19 & 26 & 21 & \\
\hline 24 & 21 & 25 & 14 & 20 & 16 & \\
\hline 23 & 20 & 20 & 21 & 22 & 22 & \\
\hline 22 & 24 & 20 & 24 & 21 & 16 & \\
\hline 26 & 21 & 24 & 19 & 20 & 22 & \\
\hline 18 & 21 & 24 & 19 & 26 & 20 & \\
\hline 21 & 24 & 23 & 22 & 21 & 22 & \\
\hline 20 & 24 & 20 & 24 & 20 & 20 & \\
\hline 22 & 21 & 22 & 19 & 23 & 21 & \\
\hline 26 & 21 & 22 & 19 & 24 & 16 & \\
\hline \multirow[t]{2}{*}{18} & 24 & 22 & 22 & 23 & 22 & \\
\hline & & $\begin{array}{l}\text { 3rd SAMPLING } \\
\text { ON 29/6/12 }\end{array}$ & & & & \\
\hline 1000 & 1330 & 2000 & 2670 & 4000 & 5330 & \\
\hline 30 & 25 & 25 & 20 & 26 & 26 & \\
\hline 26 & 25 & 27 & 25 & 28 & 21 & \\
\hline 34 & 26 & 27 & 23 & 28 & 22 & \\
\hline 25 & 26 & 26 & 25 & 26 & 23 & \\
\hline 31 & 27 & 26 & 23 & 19 & 21 & \\
\hline 25 & 31 & 25 & 23 & 26 & 22 & \\
\hline 26 & 26 & 29 & 23 & 22 & 22 & \\
\hline 29 & 27 & 29 & 28 & 22 & 22 & \\
\hline 22 & 27 & 26 & 30 & 27 & 22 & \\
\hline 30 & 26 & 29 & 23 & 28 & 21 & \\
\hline 26 & 25 & 24 & 26 & 24 & 23 & \\
\hline 20 & 26 & 25 & 25 & 25 & 21 & \\
\hline 29 & 26 & 25 & 25 & 27 & 23 & \\
\hline 31 & 28 & 26 & 26 & 27 & 23 & \\
\hline 26 & 24 & 26 & 26 & 25 & 22 & \\
\hline 31 & 30 & 26 & 27 & 24 & 21 & \\
\hline 29 & 25 & 20 & 25 & 24 & 25 & \\
\hline 28 & 26 & 30 & 23 & 24 & 24 & \\
\hline 28 & 25 & 27 & 29 & 28 & 22 & \\
\hline 28 & 23 & 30 & 24 & 25 & 24 & \\
\hline 32 & 26 & 28 & 26 & 25 & 23 & \\
\hline 26 & 28 & 22 & 22 & 26 & 25 & \\
\hline 22 & 29 & 25 & 23 & 24 & 26 & \\
\hline 29 & 23 & 28 & 21 & 24 & 22 & \\
\hline 20 & 26 & 25 & 26 & 22 & 24 & \\
\hline 28 & 30 & 27 & 24 & 24 & 25 & \\
\hline 30 & 27 & 30 & 25 & 26 & 21 & \\
\hline 32 & 31 & 27 & 21 & 26 & 24 & \\
\hline 27 & 25 & 24 & 22 & 24 & 23 & \\
\hline 25 & 25 & 26 & 23 & 24 & 21 & \\
\hline 29 & 27 & 27 & 21 & 24 & 21 & \\
\hline 31 & 27 & 19 & 23 & 24 & 22 & \\
\hline 32 & 25 & 28 & 29 & 23 & 23 & \\
\hline 25 & 27 & 24 & 22 & 24 & 26 & \\
\hline 32 & 26 & 26 & 21 & 24 & 20 & \\
\hline 36 & 27 & 24 & 24 & 24 & 25 & \\
\hline 27 & 25 & 29 & 25 & 22 & 26 & \\
\hline 27 & 23 & 25 & 24 & 24 & 23 & \\
\hline 22 & 28 & 28 & 23 & 28 & 22 & \\
\hline 30 & 29 & 24 & 24 & 26 & 22 & \\
\hline 30 & 24 & 28 & 22 & 28 & 21 & \\
\hline 30 & 25 & 26 & 27 & 22 & 23 & \\
\hline 30 & 27 & 25 & 22 & 24 & 21 & \\
\hline 22 & 26 & 27 & 23 & 25 & 22 & \\
\hline 29 & 27 & 27 & 25 & 24 & 23 & \\
\hline 20 & 25 & 26 & 28 & 24 & 24 & \\
\hline
\end{tabular}

\begin{tabular}{|l|l|l|l|l|l|l|}
\hline 28 & 23 & 26 & 27 & 24 & 25 & \\
\hline 30 & 28 & 25 & 25 & 28 & 21 & \\
\hline 32 & 29 & 29 & 23 & 25 & 22 & \\
\hline 27 & 24 & 29 & 25 & 25 & 23 & \\
\hline 25 & 25 & 26 & 28 & 26 & 24 & \\
\hline
\end{tabular}

Table 1: stocking and sampling length data for the six stocking densities.

Food conversion ratio, specific growth rate and daily weight gain

Results of food conversion ratio (FCR) specific growth rate (SGR) and daily weight gain (DWG) are shown in Table 2 . There was a great significant difference in the food conversion ratios and specific growth rates of the six stocking densities $(\mathrm{F}=\ldots . . ; \mathrm{P}<0.0001)$. FCR was lowest at stocking density of $1000 \mathrm{fry} / \mathrm{m}^{3}(1.63)$ while $5330 \mathrm{fry} / \mathrm{m}^{3}$ had the highest FCR (2.22). The daily weight gain decreased with increasing stocking density with an anomaly existing between densities of 2670 and 4000 where by 2670 had a lower daily weight gain $(0.0116 \mathrm{~g} /$ day $)$ than $4000(0.0121 \mathrm{~g} /$ day $)$ which was higher in density. Daily weight gain and specific growth rate both decreased with increasing stocking density with $5330 \mathrm{fry} / \mathrm{m}^{3}$ having almost just half the daily weight gain as $1000 \mathrm{fry} / \mathrm{m}^{3}$, however in both cases there was an anomaly at a stocking density of $2670 \mathrm{fry} / \mathrm{m}^{3}$ which had lower daily weight gain and specific growth rate than expected.

Linear regression showed a great correlation between food conversion rate and the growth rate using mean length. $\left(\mathrm{R}^{2}=0.878\right)$ with food conversion able to explain up to $77 \%$ of the length $\left(\mathrm{R}^{2}=0.77\right)$. There existed a very good correlation as well between stocking density and growth rate using mean length $\left(\mathrm{R}=0.928\right.$ and $\left.\mathrm{R}^{2}=0.86\right)$. This also happened between stocking density and feed utilization or conversion level. $\left(\mathrm{R}^{2}=0.844\right.$ and $\left.\mathrm{R}^{2}=0.712\right)$

However the effect of stocking density on growth could not be explained by the regression (ANOVA $\mathrm{P}=0.52$ ) while the effect of stocking density on feed utilization level and that of feed utilization level on growth were significantly explained by the regressions ( $\mathrm{P}=0.035$ and 0.022 respectively).

\section{Growth homogeneity}

At stocking the fry sampled fell in three homogenous groups according to length in millimeters that is, $10-11 \mathrm{~mm}$ with 13 fry, 12$13 \mathrm{~mm}$ with 29 fry and $14-15 \mathrm{~mm}$ with 8 fry hence there was some degree of homogeneity at stocking. This homogeneity was however not realized by the first sampling after one week (Table 3) as length ranged in up to 5 groups in all the six stocking densities. In the second and third week samplings, there was an observed trend of increasing homogeneity with increasing stocking density. Homogenous growth was observed in the high stocking densities with all the samples in the highest density ( $5330 \mathrm{fry} / \mathrm{m}^{3}$ ) falling in just three groups and 36 out of the 50 sampled being below $24 \mathrm{~mm}$.

\begin{tabular}{|l|l|l|l|l|}
\hline $\begin{array}{l}\text { STOCKING } \\
\text { DENSITY(fry/ } \\
\text { m3 }\end{array}$ & $\begin{array}{l}\text { AVERAGE } \\
\text { BODY } \\
\text { WEIGHT(g) }\end{array}$ & $\begin{array}{l}\text { TOTAL } \\
\text { WEIGHT(g) }\end{array}$ & $\begin{array}{l}\text { NUMBER OF } \\
\text { SURVIVALS }\end{array}$ & $\begin{array}{l}\text { PERCENTAGE } \\
\text { SURVIVAL }\end{array}$ \\
\hline 1000 & 0.43 & 600 & 1395 & 93 \\
\hline 1330 & 0.35 & 665 & 1900 & 95 \\
\hline 2000 & 0.34 & 989 & 2762 & 92.1 \\
\hline 2670 & 0.32 & 1240 & 3875 & 96.9 \\
\hline 4000 & 0.308 & 1608 & 5220 & 87 \\
\hline 5330 & 0.24 & 1589 & 6621 & 82.8 \\
\hline
\end{tabular}

Table 2: Survival rates and significance levels for the stocking densities. 
The number of fry in lower higher classes (longer fry) also decreases as the stocking density increases hence shorter fry produced (Tables $2,4,5,6)$.

\section{Discussion}

\section{Stocking density and growth}

The effect of population density is usually seen to be either density dependent or density independent. Wiener et al [6] suggested that stocking density that negatively affect fish growth are density dependent. In the current study, the first sampling showed no significant effect of stocking density on growth while the second and third showed a great significant effect of stocking density on growth. This can be explained by the fact that at appropriate stocking density before attainment of carrying capacity, the fish grow properly thus at this stage stocking density did not affect fish growth by sampling one. This can also be explained by the slow growth after immediate stocking of fry due to stress from the harvesting process thus no extreme utilization of resources in the hapa.

By the second sampling the highest stocking density (5330 fry/ $\mathrm{m}^{3}$ ) was significantly different from the rest of the stocking densities. This indicated that as early as two weeks it had reached its carrying capacity which is one of the reasons to explain reduced growth rate. In sampling three, there was no significance between density 4000 and $5330 \mathrm{fry} / \mathrm{m}^{3}$ implying that in a time period of one week $4000 \mathrm{fry} / \mathrm{m}^{3} \mathrm{had}$ also increased in biomass to carrying capacity thus affecting growth. $2670 \mathrm{fry} / \mathrm{m}^{3}$ density reported lower growth rates than $4000 \mathrm{fry} / \mathrm{m}^{3}$ even though they did not differ significantly, this can be explained by the high survival rates of $96.9 \%$ as compared with $82 \%$ in $4000 \mathrm{fry} / \mathrm{m}^{3}$ making them have insignificantly different number of fry. These results are in agreement with Yousif [7] and Breine et al. [8] who reported that it's a generally accepted principle that increasing stocking density adversely affects fish growth. High stocking densities are associated with stress, competition for food and living space, voluntary appetite suppression and more energy expenditure in antagonistic interactions $[9,10]$. According to Bacellos et al [11], stress leads to increased cortisol production by even resting plasma cortisol and these increases with increasing stocking density, he continues that higher cortisol concentrations are considered as chronicle response to social stress due to high stocking density and this impairs fish growth due to mobilization of dietary energy by physiological alterations caused by stress.

\section{Survival rate}

In this study, the high survival rates of tilapia fry at high stocking density $\left(82.9 \%\right.$ at $\left.5330 \mathrm{fry} / \mathrm{m}^{3}\right)$ indicate amenability of tilapia to intensive culture [3]. However, this can also be attributed to favorable environmental conditions during the experiment. This is in agreement with El Sherif [11] who found out that survival of up to $100 \%$ could be linked to good environmental conditions. Lower survivals were realized when stocking density was higher than $2670 \mathrm{fry} / \mathrm{m}^{3}$. This means that tilapia fry can survive at high densities of up to around $2670 \mathrm{fry} / \mathrm{m}^{3}$ but at extremely high densities the survival rate is significantly affected, this can be due to stress, decreasing water quality due to increased biomass and other density dependent factors at this point not only affecting growth rate, but also cause increase mortality rates. Thus 4000 fry $/ \mathrm{m}^{3}$ and $5330 \mathrm{fry} / \mathrm{m}^{3}$ are in agreement with Osofero [12] who found an inverse relationship between stocking density and survival while $1000,1330,2000$ and $2670 \mathrm{fry} / \mathrm{m}^{3}$ are in line with Alhassan [3] who realized no effect of stocking density on survival. The high stocking densities (4000 fry $/ \mathrm{m}^{3}$ and $5330 \mathrm{fry} / \mathrm{m}^{3}$ ) are not in agreement with Alhassan [3] because he considered very low stocking densities $(8,10$ and $12 \mathrm{fry} / \mathrm{m}^{3}$ ) thus could not find the limit to the insignificant effect stocking density on survival as the current study did (Figure 5).

\section{Growth homogeneity}

Yousif [7] realized that as initial size was homogenous for all densities and ample daily feedings done, one would expect fish in each density to be slightly but not significantly different in final body sizes. In this study however although the initial size was homogenous stocking density had an effect on final size among individuals of initially the same size. The little or no homogeneity in first sampling occurring at high stocking density can be due to tilapia's aggressive behavior [4] where some fish maintain a domain position, grow faster while others in low dominance hierarchy end up being chronically stressed leading to appetite suppression, reduced food intake and low growth rates thus decreasing homogeneity in growth of fish from the same brood stock and feed on the same food under the same environment. In the second and third sampling growth homogeneity however increased with increased stocking density with $5330 \mathrm{fry} / \mathrm{m}^{3}$ being the most homogeneous. This can be related to studies on Artic charr. According to Jobling 1985 [13], change in interspecies relationships that defend territories is reduced as stocking density increases to extreme in Artic charr, this could also explain findings that a positive relationship exists between stocking density and homogeneity in Artic Charr [14] and thus highest homogeneity at high tilapia stocking densities in this study. This is still in agreement with Kanawabe [15] who worked on Salmoids and found out that rearing them at high densities reduces territorial behavior and breaks the dominance hierarchy. This reduces the chronic stress by fish in low dominance hierarchy thus improving their growth; however the improved growth doesn't indicate that every individual is growing fast but rather increased growth of slow growers and reduced growth of fast growers due to reduced dominance over food.

Since Nile tilapias raised in tropics are generally fast growing with little slow growers, there is a general significant decrease in growth rate at high densities and high growth homogeneity. This finding is however not in agreement with the negative relationships found between

\begin{tabular}{|c|c|c|c|c|c|c|c|}
\hline $\begin{array}{l}\text { STOCKING DENSITY (Fryl } \\
\left.\qquad \mathbf{M}^{3}\right)\end{array}$ & $\begin{array}{l}\text { TOTAL WEIGHT } \\
\text { STOCKED(G) }\end{array}$ & $\begin{array}{l}\text { TOTAL WEIGHT } \\
\text { HARVESTED (G) }\end{array}$ & TOTAL WEIGHT GAIN(G & $\begin{array}{c}\text { TOTAL FEEDS GIVEN } \\
\text { (G.) }\end{array}$ & FCR & SGR (\%) & DWG(g/day \\
\hline 1000 & 45 & 599.85 & 555 & 906.5 & 1.63 & 4.4 & 0.0167 \\
\hline 1330 & 60 & 665 & 605 & 1136.8 & 1.88 & 4.5 & 0.0133 \\
\hline 2000 & 90 & 938.4 & 846.4 & 1622.4 & 1.92 & 4.4 & 0.0129 \\
\hline 2670 & 120 & 1193.81 & 1073.81 & 2021.6 & 1.88 & 4.2 & 0.0116 \\
\hline 4000 & 180 & 1827 & 1647 & 3140.4 & 1.91 & 4.3 & 0.0121 \\
\hline 5330 & 240 & 1589.76 & 1349.76 & 2997.6 & 2.22 & 3.8 & 0.0088 \\
\hline
\end{tabular}

Table 3: Food conversion ratio, specific growth rate and daily weight gain for the six stocking densities. 


\begin{tabular}{|l|c|c|c|c|c|c|}
\hline & $\mathbf{1 0 0 0}$ & $\mathbf{1 3 3 0}$ & $\mathbf{2 0 0 0}$ & $\mathbf{2 6 7 0}$ & $\mathbf{4 0 0 0}$ & $\mathbf{5 3 3 0}$ \\
\hline $10-13$ & 1 & 4 & 0 & 0 & 1 & 5 \\
\hline $13-14$ & 13 & 3 & 13 & 9 & 14 & 11 \\
\hline $15-16$ & 13 & 18 & 14 & 18 & 21 & 16 \\
\hline $17-18$ & 12 & 16 & 8 & 12 & 6 & 12 \\
\hline $19-20$ & 10 & 8 & 15 & 10 & 8 & 5 \\
\hline $21+$ & 1 & 1 & 0 & 1 & 0 & 1 \\
\hline
\end{tabular}

Table 4: Length frequency groups for week one sampling in millimeters.

\begin{tabular}{|l|c|c|c|c|c|c|}
\hline & $\mathbf{1 0 0 0}$ & $\mathbf{1 3 3 0}$ & $\mathbf{2 0 0 0}$ & $\mathbf{2 6 7 0}$ & $\mathbf{4 0 0 0}$ & $\mathbf{5 3 3 0}$ \\
\hline $13-19$ & 4 & 8 & 1 & 6 & 1 & 28 \\
\hline $19-20$ & 8 & 13 & 15 & 23 & 19 & 10 \\
\hline $21-22$ & 16 & 13 & 11 & 9 & 17 & 12 \\
\hline $23-24$ & 10 & 12 & 19 & 6 & 10 & 0 \\
\hline $25-26$ & 8 & 4 & 4 & 6 & 3 & 0 \\
\hline $27+$ & 4 & 0 & 0 & 0 & 0 & 0 \\
\hline
\end{tabular}

Table 5: Length frequency groups for week two sampling in millimeters.

\begin{tabular}{|l|c|c|c|c|c|c|}
\hline & $\mathbf{1 0 0 0}$ & $\mathbf{1 3 3 0}$ & $\mathbf{2 0 0 0}$ & $\mathbf{2 6 7 0}$ & $\mathbf{4 0 0 0}$ & $\mathbf{5 3 3 0}$ \\
\hline $18-24$ & 4 & 7 & 3 & 22 & 7 & 36 \\
\hline $24-25$ & 2 & 22 & 14 & 15 & 26 & 10 \\
\hline $26-27$ & 18 & 12 & 19 & 8 & 10 & 4 \\
\hline $28-29$ & 18 & 6 & 11 & 4 & 7 & 0 \\
\hline $30-31$ & 7 & 2 & 3 & 1 & 0 & 0 \\
\hline $32+$ & 1 & 1 & 0 & 0 & 0 & 0 \\
\hline
\end{tabular}

Table 6: Length frequency groups for week three sampling in millimeters.

stocking density and growth homogeneity in red tilapia $(4,16)$. Joblings [16] realized that proper dominance hierarchies in Artic charr were established in three months so it can also be assumed that three weeks was not enough time for establishment of proper social interactions and dominance hierarchies in this study.

Food conversion ratio (FCR), specific growth rate (SGR) and daily weight gain (DWG)

Food conversion ratio increased with increasing stocking density thus as stocking densities increased the fry became less efficient in utilizing the food for somatic growth. This is attributed to increased stress due to decreasing water quality as stocking density is increased far beyond the carrying capacity [17]. This is in agreement with Guimareaes et al. [18], who found out that efficient utilization of diets may vary within a single species because of not only the particular strain of fish but also environmental factors. On the contrary, Osofero [12] reported no effect of stocking density on food conversion ratio which he attributed to using the same feed in the same environment. Hence in the current study the environment played a very great role in influencing the food conversion ratio through water quality.

Daily weight gain and specific growth rate generally decreased with increasing stocking density indicating the decreasing feed utilization ability as explained above. However the anomaly at $2670 \mathrm{fry} / \mathrm{m}^{3}$ is attributed to the very high survival rate (Figure 4) which made the carrying capacity to be realized faster. This affected growth negatively thus lowering both the specific growth rate and daily weight gain.

\section{Conclusions and Recommendations}

\section{Conclusion}

- The results in this study demonstrate that increasing stocking density in Nile tilapia fry results into homogenous growth and survival rate is only significantly affected at extremes of stocking density.

- Feed conversion ratios, specific growth rates and daily weight gain are as well affected by stocking density in this study.

- Many individuals grow at less than their maximum potential rate at high stocking densities thus growth homogeneity

- Fish growth is plastic hence the proper growth rate lacking at some stocking densities can be regained in secondary nursing hapas by proper stocking and growth homogeneity at grading, but at the same time larval fish are very delicate hence need proper management and this is can be achieved when they are in one unit which calls for higher stocking density. Thus survival of fish is the most important factor in the primary nursing hapas since lost fish can't be regained in the following rearing stages and this rules of stocking densities of 4000 fry/ $\mathrm{m}^{3}$ and $5330 \mathrm{fry} / \mathrm{m}^{3}$

- Further research is needed to understand how stocking density affects growth and survival in secondary nursing happas and other grow out stages that follow afterwards [19-25].

\section{Recommendations}

According to this study, it is recommended to have stocking densities not exceeding $2670 \mathrm{fry} / \mathrm{m}^{3}$ in hapas placed in earthen but depending on one's required output and resources available to manage carrying capacity this can vary.

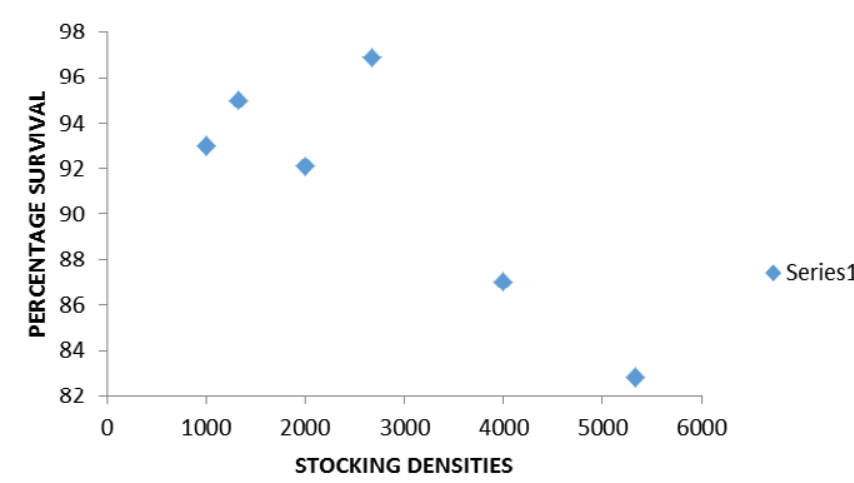

Figure 4: A correlation between survival and stocking density.

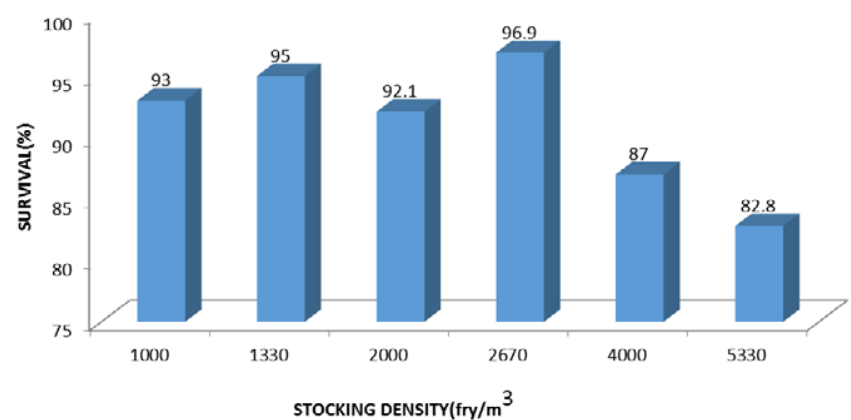

Figure 5: Survival rates for the six stocking densities at the end of the experiment. 
Citation: Ronald N, Gladys B, Gasper E (2014) The Effects of Stocking Density on the Growth and Survival of Nile Tilapia (Oreochromis niloticus) Fry at Son Fish Farm, Uganda. J Aquac Res Development 5: 222 doi:10.4172/2155-9546.1000222

\section{Acknowledgement}

My sincere gratitude goes to the following;

1. God the almighty for all the success that has come my way right from the start of my academic struggles up to this stage.

2. My supervisor Dr. Gladys Bwanika of Makerere University School of Biological Sciences for her unending guidance thought the research.

3. Management and workers of SON fish farm especially the production manager Dr. Damien Desperez and the pond supervisor Mr. Gasper for their help and hospitality during the experiment.

\section{References}

1. El-Sayed AM (2002) Effects of Stocking Density and Feeding Levels on Growth and Feed Efficiency of Nile Tilapia (Oreochromis niloticus) Fry. Aqua Res 32 621-625.

2. Food and Agricultural Organisation of the United Nations (Fao), National Aquaculture Sector Overview (2012).

3. Alhassan EH, Abarike ED, Ayisi LC (2012) Effects of Stocking Density on the Growth and Survival of Oreochromis niloticus Cultured in Hapas in a Concrete Tank. Afri J Agric Res. 7: 2405-2411.

4. Huang WB, Chiu TS (1997) Effects of Stocking Density on Survival, Growth, Size Variation and Production of Tilapia Fry. Aqua Res 28: 165-173.

5. Food and Agricultural Organisation of the United Nations (Fao), Fisheries and Aquaculture Department. Culture Species Information Programme, Oreochromis niloticus (Linnaeus 1758 ).

6. Wiener JG, Hameman WR (1982) Growth and Condition of Bluegills in Wisconsin Lakes, Effects of Population Density and Lake Ph. Transition of the American Fishery Society 111: 761-767.

7. Yousif Om (2002) The Effects of Stocking Density, Water Exchange Rate Feeding Frequency and Grading on Size Hierarchy Development in Juvenile Nile Tilapia (Oreochromis Niloticus L.). Emir J Agric Sci 14: 45-51.

8. Breine JJ, Ngeuga D, Ollevia F (1996) A Comparative Study of the Effects of Stocking Density and Feeding Regimes on Growth of Tilapia Cameronenosis and Oreochromis niloticus in Fish Culture in Cameroon. Aquat Living Resour 9: 51-56.

9. Yi Y, Lin CK, Diane J (2004) Stocking Density and Fertilization Regimes of Nile Tilapia (Oreochromis Niloticus) Production In Ponds With Supplementa Feeding. Proceedings of Sixth International Symposium in Aquaculture. R Boliviar, G.Mair \& K.Ktzsmour. Eds. Manilla Phillipines 487-499.

10. Bachellos LG, Lulhier F (1999) The Effects of Stocking Density and Socia Interaction on Acute Stress Response in Nile Tilapia (Oreochromis niloticus). Aquac.Res 30:887-892.

11. El-Sherif M, El-Feky MI (2009)Performance of Nile Tilapia (Oreochromis niloticus) Fingerings Effect of Ph. Inter J Agric Biolo11: 297-300.
12. Osofero SA,Otubusin SO, Daramola JA( 2009) Effects of Stocking Density on Tilapia (Oreochromis niloticus Linnaeus 1757) Growth and Survival in BambooNet Cages Trial. Afr J Biotech 8: 1322-1325.

13. Jobling M (1985) Physiological and Social Constraints on Growth of Fish With Special Reference to Arctic Charr, Salvelinus alpinus L. Aquaculture 44: 83-90.

14. Wallance JC, Colbeinshaun AG (1988) The Effects of Stocking Density on the Early Growth in Arctic Charr, Salvelinus Alpinus (L) Aquaculture 73: 101-110.

15. Kawanabe H (1969) The Significance of Social Structure in Production of Ayu (Pleco-Glousus Altivalis).Symposium on Salmon and Trout in Streams. University of British Columbia, Vancouver 243-251.

16. Wetanabe WO, Clark JH, Olla BL (1990) Culture of Florida Red Tilapia in Marine Cages. The Effects of Stocking Density and Dietary Protein in Growth Aquaculture 90: 123-134.

17. Joblings M, Wandsvik A (1983) Effects of Social Interactions on Growth Rates and Conversion Efficiency of Arctic Charr, Salvelinus alpinus L. J Fish Biology 22:577-584.

18. Guimaraes IG, Pezzato LE, Barros MM, Tachibana L (2008) Nutrient Digestability of Cereal Grain Products and By-Products in Extruded Diets for Nile Tilapia. J World Aqua Soc 39: 181-789.

19. Aksungur N, Aksungur M, Akbulur BK (2007) The Effects of Stocking Density on Growth Performance, Survival and Food Converstion Ratio of Turbot (Psetta maxima ) in the Net Cages on The Southern East Cost of Black Sea. Turkish J Fish Sci 7: 147-152.

20. Damboo WB, Reina KJ (1992) Effects of Stocking Density on Growth and Survival of Nile tilapia (Oreochromis niloticus) Fry in Hatchery. Aqua. and Fisheries Mag'ment133:71-80.

21. Fox Mg, Flower Dd (1990) Effects of Fish Density on Growth, Survival and Food Consumption by Juvenile Wallayes in Rearing Ponds. Transactions of the American Fishery Society 119: 112-121.

22. Das GN, Mamun F, Barua P, Siddique AAM, Chowdhury MSN (2010) Survivality of Mono-Sex Tilapia (Oreochromis niloticus) Fry Using 17-Alpha Methyltestesterone in a Commercial Hatchery of Chittagony, Bangladesh. J Aquacult Feed Sci Nutr 2:16-24.

23. Macintosh DJ, De Silva SJ (1984) The Influence of Stocking Density and Food Ration on Fry Survival and Growth in Oreochromis mossambicus and Oreochromis niloticus Xo. Aureus Male Hybrids Reared in a Closed Recirculated System. Aqua. 41:345-358.

24. Khattab Yar, Abdel-Tawwab M, Ahmed MH (2004) Effects of Protein Level and Stocking Density on Growth Performance, Survival Rate, Feed Utilization and Body Composition on Nile Tilapia Fry (Oreochromis niloticus L.) Proceedings of The $6^{\text {th }}$ International Symposium on Tilapia in Aquaculture, Manilla, Phillipines Bfar, 264-276.

25. Suman BC, Samir B (2010) Effects of Stocking Density on Monosex Nile Tilapia Growth During Pond Culture in India. World Acad Sci Eng \& Tech 68. 